Vieira Serra, F.C., \& Bezerra Almeida, E. Jr. (2021). Phytosociology, successional level, and conservation of the woody component in a "restinga" of Maranhão island, Brazil. Revista de Biología Tropical, 69(2), 743-754. https://doi.org/10.15517/rbt.v69i2.42265

https://doi.org/10.15517/rbt.v69i2.42265

\title{
Phytosociology, successional level, and conservation of the woody component in a "restinga" of Maranhão island, Brazil
}

\author{
Flávia Cristina Vieira Serra ${ }^{1}$ \\ Eduardo Bezerra Almeida Jr. ${ }^{2 *}$
}

1. Programa de Pós-Graduação em Biodiversidade e Conservação, Universidade Federal do Maranhão, São Luís, Maranhão, Brazil; flavia_biologia@hotmail.com

2. Departamento de Biologia, Universidade Federal do Maranhão, São Luís, Maranhão, Brazil; ebaj25@yahoo.com.br (Correspondence*)

Received 11-VI-2020. Corrected 08-IV-2021. Accepted 11-VI-2021.

\begin{abstract}
Introduction: The "restingas" (coast vegetation) can serve as a species corridor in ecotonal environments due to the particulars regarding the composition of the flora. The studies covering the entire length of the Maranhão state coast are necessary to understand the diversity and distribution of plant species present in the "restingas". Objective: The objective of this study was to characterize the structure and conservation of the woody vegetation of a "restinga" in Maranhão. Methods: Phytosociological sampling of woody vegetation was carried out using the quadrants method, followed by classification of species by successional group; in addition to analyzing the diametric and hypsometric data of the populations whose species presented the highest importance value (IV). Results: In total, 24 species and 16 families were identified, $72 \%$ of which were classified in the initial stages of succession. The values of $\mathrm{H}^{\prime}$ and $\mathrm{J}^{\prime}$ were 2.637 nat.ind $^{-1}$ and 0.830 , respectively. The mean height and diameter were $2.1 \mathrm{~m}$ and $27.66 \mathrm{~cm}$, respectively. The species Coccoloba ramosissima Wedd., Byrsonima crassifolia (L.) Kunth, Anacardium occidentale L., Manilkara triflora (Allemão) Monach, and Astrocaryum vulgare Mart. presented the highest IVs. Conclusions: It was observed that characteristics such as size, power of regrowth, and ease of regeneration processes could be useful for choosing target species for recovery actions in coastal areas.
\end{abstract}

Key words: phytosociology; diametric structure; vertical distribution; Maranhão state; environmental restoration.

The restinga has a high environmental relevance in view of the vegetal and physiognomic mosaic, its conservation is essential due to the intense threat caused by anthropic actions (Dias \& Soares, 2008). In the Northeast region of Brazil, despite the increase in research for this ecosystem, as in States of the Bahia: Menezes, Santana, Silva, Silva and Araújo (2012), Santos, Zickel and Almeida Jr. (2015); Pernambuco: Almeida Jr., Santos-Filho, Araújo and
Zickel (2011), Cantarelli, Almeida Jr., SantosFilho and Zickel (2012a); Alagoas: Medeiros, Santos-Filho, Almeida Jr., Pimentel and Zickel (2010); Rio Grande do Norte: Almeida Jr. and Zickel (2012), Medeiros, Almeida Jr., Abreu, Santos-Filho and Zickel (2014); Piauí: Santos-Filho, Almeida Jr. and Zickel (2013a); Paraíba: Vicente, Almeida Jr., Santos-Filho and Zickel (2014); Sergipe: Santana, Rocha, Oliveira, Prata and Ribeiro (2020) - the existing 
knowledge about wealth and diversity still does not correspond to the coastal territorial extension of the region. What makes broader analysis impossible due to the particularities in various aspects of its biodiversity and conservation status.

Considering, in particular the Maranhão coastline, the knowledge about restinga vegetation is still restricted to a few floristic studies (Cabral-Freire \& Monteiro, 1993; Serra, Lima, \& Almeida Jr., 2016; Silva, Araujo, \& Almeida Jr., 2016a; Amorim, Amorim, \& Almeida Jr., 2016a; Lima \& Almeida Jr., 2018) and phytosociological records (Araujo, Silva, \& Almeida Jr., 2016; Amorim, Santos-Filho, \& Almeida Jr., 2016b; Machado \& Almeida Jr., 2019; Almeida Jr., Correia, \& Santos-Filho, 2020). These studies represent only a small part of the coast in Maranhão, which is in turn in a large transition area between vegetation in the Amazon and Cerrado domain (Silva et al., 2016b).

Knowing that restingas can serve as a species corridor in ecotonal environments, studies covering the entire length of the Maranhão coast are necessary to understand the diversity and distribution of plant species present in the restingas (Castro, Moro, \& Menezes, 2012; Serra, Lima, \& Almeida Jr., 2016).

One of the ways to obtain information about plant species for conservation is related to knowledge of the structure of the plant community (Nadkarni, Mcintosh, \& Cushing, 2008). Thus, height and diameter measurements could provide data on the plant community or be used for the analysis of one or more species of interest in the succession processes. The existence of different strata in the plant community enables greater diversity of micro-habitats, which can increase the diversity of species and ecological interactions (Souza, Souza, Gama, \& Leite, 2003). Therefore, vertical stratification could contribute as an indicator of environmental sustainability of a forest, influencing wealth, diversity, and biomass production (Souza et al., 2003) among other factors.

Therefore, evaluation of conditions regarding the dynamics of the forest can generate subsidies for future forest management actions based on indications about the populations in the development of the plant community (Siminski, Mantovani, dos Reis \& Fantini, 2004). Considering the need for data related to the structure of the woody vegetation of the restingas in Maranhão (Serra et al., 2016; Machado \& Almeida Jr., 2019; Almeida Jr. et al., 2020), the current study aims to characterize the structure of woody vegetation, analyze the diametric and hypsometric distribution of species of greatest ecological importance, and indicate the level of succession to support future research on recovery and or management of coastal areas.

\section{MATERIALS AND METHODS}

Study area: The collections were carried out in a restinga in the Eastern part of Maranhão Island $\left(02^{\circ} 38^{\prime} 47.85^{\prime \prime} \mathrm{S} \& 44^{\circ} 09^{\prime} 05.76\right.$ " W), on the Sítio Aguahy. The area is owned by Companhia Farmacêutica Quercegen Agronegócios I Ltda., in the municipality of São José de Ribamar, Maranhão state (Fig. 1).

The Sítio Aguahy has an area of 400 ha consisting of a transition between fragments of regenerating Amazon forest, mangrove, and restinga (Serra et al., 2016; Marinho, Muniz, \& Azevedo, 2018). The fragment denominated restinga occupies an area of approximately 50 ha, consisting of vegetation from herbaceous to arboreal stratum, presenting physiognomies of floodable fields, non-floodable shrubby, and non-floodable forest (Serra et al., 2016) (Fig. 2). The climate of the region, according to the classification of Köppen (1948), is of the Aw type, having two distinct seasons: a rainy season that extends from January to June and a dry season that begins in July and extends until December. The average rainfall index of Maranhão Island is approximately $2000 \mathrm{~mm} /$ year and the average temperatures throughout the year vary between 25.5 and $28.6{ }^{\circ} \mathrm{C}$ (INMET, 2016).

Vegetation sampling: Phytosociological sampling was carried out in 2015 and followed 

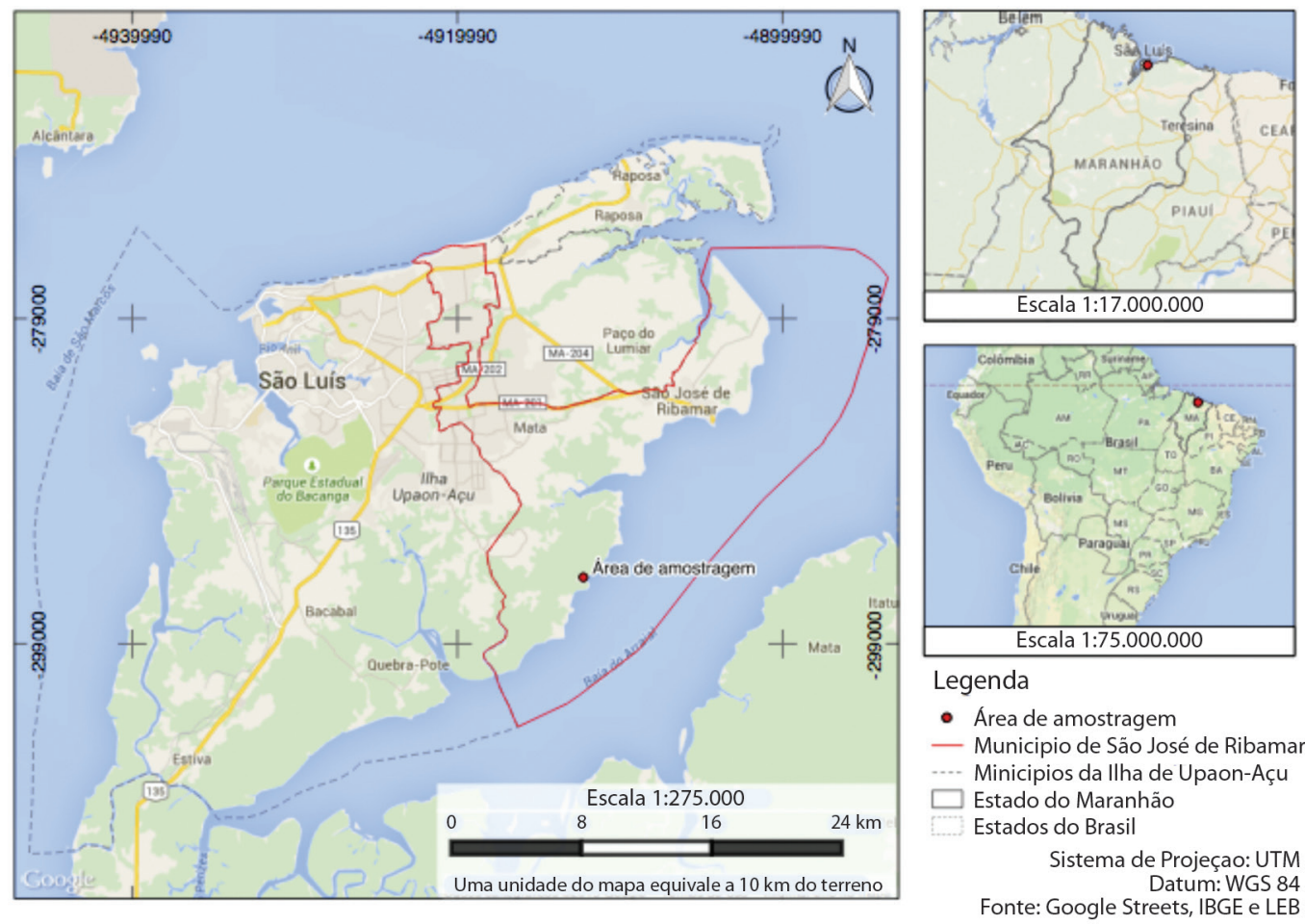

Fig. 1. Location of Ilha do Maranhão, where the restinga of Sítio Aguahy is located, municipality of São José de Ribamar, Maranhão state. Source D. Muniz.

the quadrants method (Cottam \& Curtis, 1956). In each quadrant, the individual closest to the central point that meets the inclusion criteria of the sample is marked and identified. Then its distance from the central point of the quadrant is recorded (Durigan, 2003). Five transections were plotted on area, arranged in parallel, each measuring $100 \mathrm{~m}$. Ten points were allocated to each transection, with a distance of $10 \mathrm{~m}$ between each point, totaling 50 points. Individuals woody with a diameter at ground height $(\mathrm{DGH}) \geq 3 \mathrm{~cm}$ were measured. In the case of tillered individuals (plants that had branches at the base of the stem) all the trunks were measured and the sum of the perimeters of each tiller was used to represent the final value of the plant diameter.

This sample size has been considered satisfactory for restinga areas, achieving sample sufficiency through stability in the species saturation curve (Zickel et al., 2015). In addition, this sampling method follows the studies carried out for the woody strata of the Northeast region (Medeiros et al., 2010; Almeida Jr. \& Zickel, 2012; Santos-Filho et al., 2013a; Medeiros et al., 2014; Machado \& Almeida Jr., 2019).

For the analysis of the community organization, relative density (RD), relative frequency (RF), basal area (BA), relative dominance (RDO), importance value (IV), Shannon diversity index (H'), Pielou equability index (J'), and total wealth (S) were calculated using the FITOPAC 2.0 package (Shepherd, 2009).

For the analysis of the diametric distribution, a histogram was elaborated with the number of individuals per class of diameter $(10 \mathrm{~cm}$ interval), representing the plant community. To 

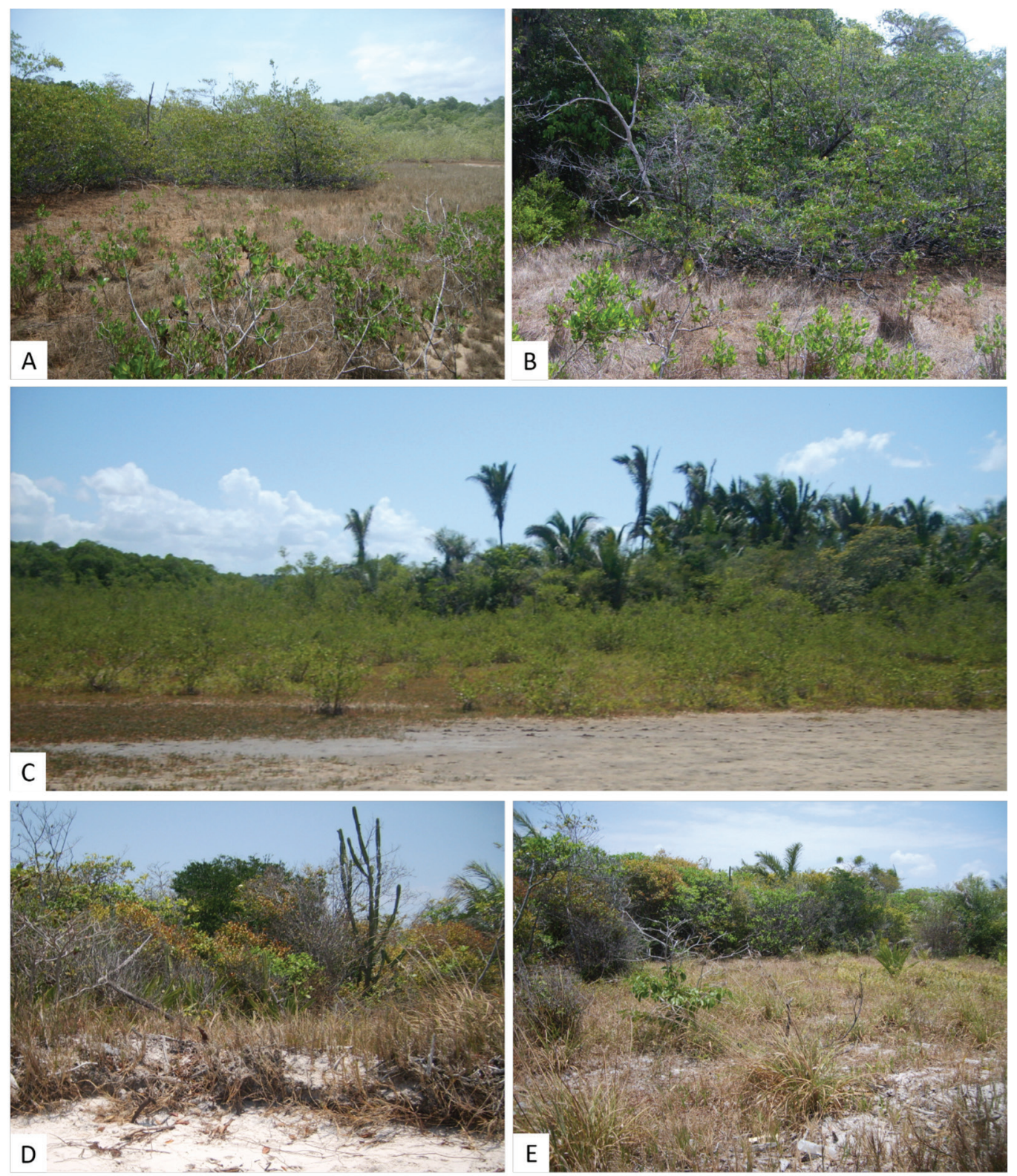

Fig. 2. General aspect of restinga vegetation of Sítio Aguahy is located, municipality of São José de Ribamar, Maranhão state. A. and B. Physiognomies non-floodable shrubby, C. physiognomies non-floodable forest, D. and E. stretch with herbaceous vegetation in physiognomies non-floodable shrubby. Source E.B. Almeida Jr.

characterize the occupation of vertical space, a histogram was created with the number of individuals per class of height ( $1 \mathrm{~m}$ intervals).

Collection and identification of botanical material: The plants were collected and processed according to the usual methodology (Peixoto \& Maia, 2013). Next, the material was identified through comparison with herbarium material and using specialized literature (Melo, 1996; Rosário, Secco, Amaral, Santos, \& Bastos, 2005; Margalho, Rocha, \& Secco, 
2009; Alexandrino, Sousa, \& Bastos, 2011; Menezes, Taylor, Machado, Coelho, \& Correia, 2011; Lima \& Almeida Jr., 2020; among others). After identification, the exsiccatae were incorporated into the collection of the Herbário MAR, Dep. Of Biology, of the Federal University of Maranhão (UFMA). The list of families followed the APG IV (2016) classification system. Confirmation of the spelling of species and names of authors was carried out by consulting the sites Flora do Brasil (http:// floradobrasil.jbrj.gov.br/) and Tropicos (http:// www. tropicos.org/). The classification of species by successional group was carried out through specialized literature according to the criterion suggested by Gandolfi, Leitão and Bezerra (1995).

\section{RESULTS}

In total, 24 species were sampled, distributed in 16 families (Table 1). The families with the highest specific wealth were Asteraceae and Rubiaceae (with three species each), and Malpighiaceae, Ochnaceae, and Sapotaceae (with two species each), corresponding to $60 \%$ of the total species sampled (Table 1).

Of the 24 species sampled, the majority (18) were classified as early pioneer and secondary, corresponding to $75 \%$ of the total species. Species characterized as "unclassified" were those that remained indeterminate or identified down to the gender level. These data allow us to infer that the studied community is in an initial succession stage (Table 1).

The species Coccoloba ramosissima Wedd., Byrsonima crassifolia (L.) Kunth, Anacardium occidentale L., Manilkara trifloral (Allemão) Monach., and Astrocaryum vulgare Mart. presented the highest importance values (IV) and the highest number of individuals (Table 1). The total basal area was $1943 \mathrm{~m}^{2}$ $\mathrm{ha}^{-1}$, the value found for the Shannon diversity index ( $\left.\mathrm{H}^{\prime}\right)$ was 2.637 nat.ind $^{-1}$, and for the Pielou equability index ( $\mathrm{J}$ ') was 0.830 .

The mean diameter of the species found was $27.66 \mathrm{~cm}$ and the maximum $44 \mathrm{~cm}$. The largest number of individuals $(82.5 \%)$ was registered in the first diameter class, corresponding to the intervals from 3 to $13 \mathrm{~cm}$ (Fig. 3A). The five species with the greatest IVs were Coccoloba ramosissima, Byrsonima crassifolia, Anacardium occidentale, Manilkara triflora, and Astrocaryum vulgare with a predominance of young individuals belonging to the first diametric classes.

The mean height found in the shrub-tree component was $2.1 \mathrm{~m}$ and the maximum was $6 \mathrm{~m}$. The majority of individuals $(97.5 \%)$ were registered between the second and fourth height classes, corresponding to intervals of 1 to $4 \mathrm{~m}$ (Fig. 3B). With respect to the species with the highest IVs, there was a predominance of individuals in the range of 1 to $2 \mathrm{~m}$, confirming, together with the diameter, the greater number of young individuals.

Coccoloba ramosissima presented 71.4 $\%$ of the individuals in the first classes of diameter $(3-18 \mathrm{~cm})$ (Fig. 4A). This species was predominant in the first height class, corresponding to the interval between 1 to $2 \mathrm{~m}$ (Fig. 4B). Byrsonima crassifolia presented $97 \%$ of individuals in the first two diameter classes (Fig. 4A) and $68.75 \%$ of individuals between the first and second height classes (Fig. 4A).

Anacardium occidentale stood out in the first and second diameter classes $(3-13 \mathrm{~cm})$, with a gap in the third diameter class (13-18 $\mathrm{cm}$ ) (Fig. 4A), whereas the hypsometric distribution (Fig. 4B) did not present any discontinuities. The gap observed may be related to the presence of branches and not to the absence of trees of a certain age. This observation is necessary since the branches are added to give the value of the final diameter of the plant, which contributes to increasing the value related to the caliber of the plant.

The vertical structure was shown to be discontinuous for Manilkara triflora, demonstrating regularity in the diametric distribution (Fig. 4A) and presenting gaps in the registration of individuals in the range of 2.5 to 3.5 m (Fig. 4B). The species Astrocaryum vulgare presented a diametric (Fig. 4A) and hypsometric (Fig. 4B) distribution with many young individuals and few adult individuals. 


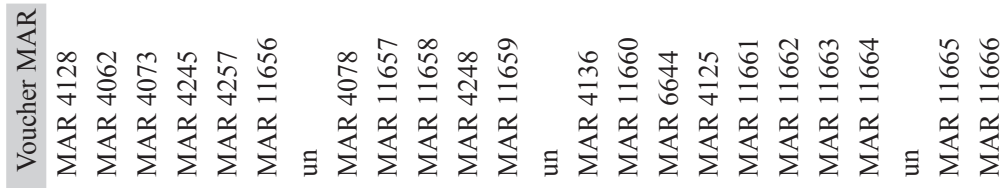
居 ت.

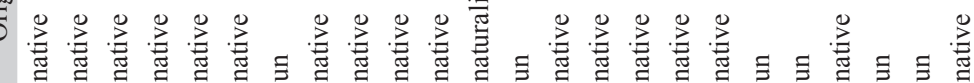

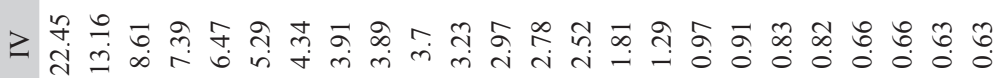

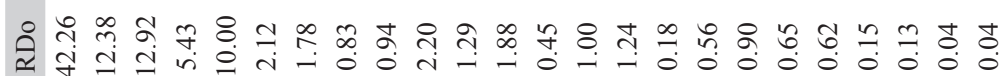

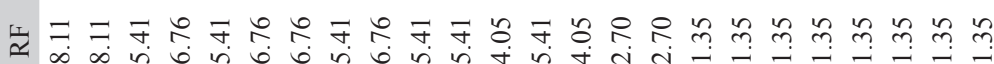

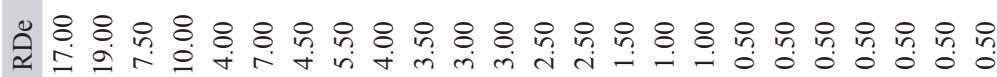

I -

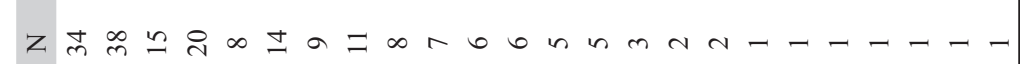

之

5

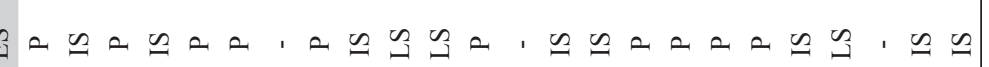

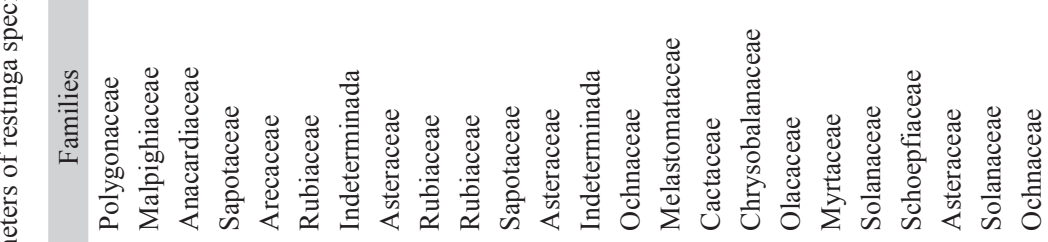

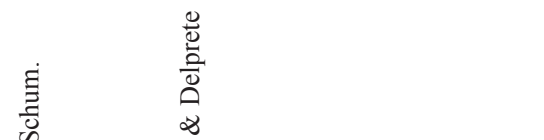

窟

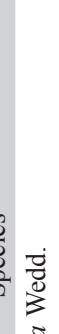
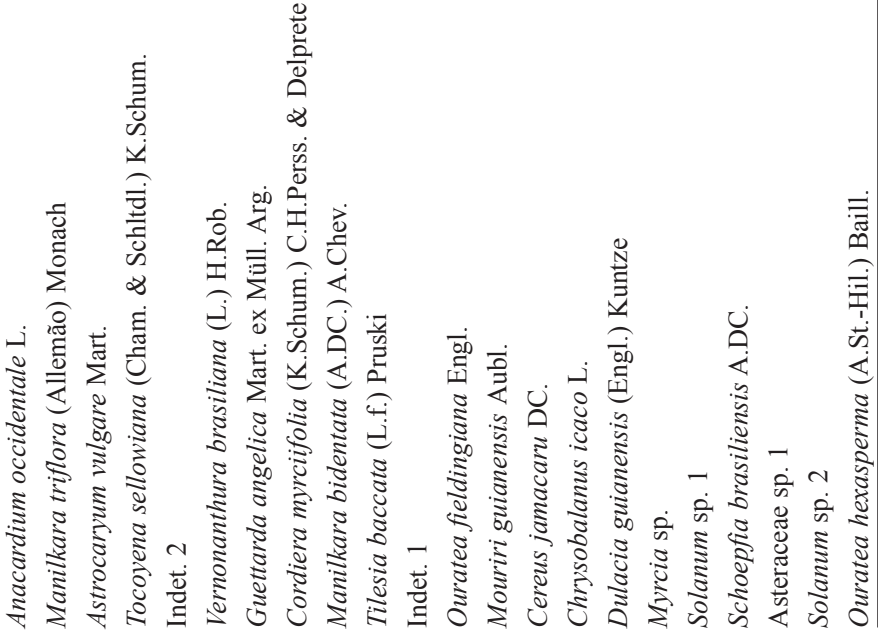

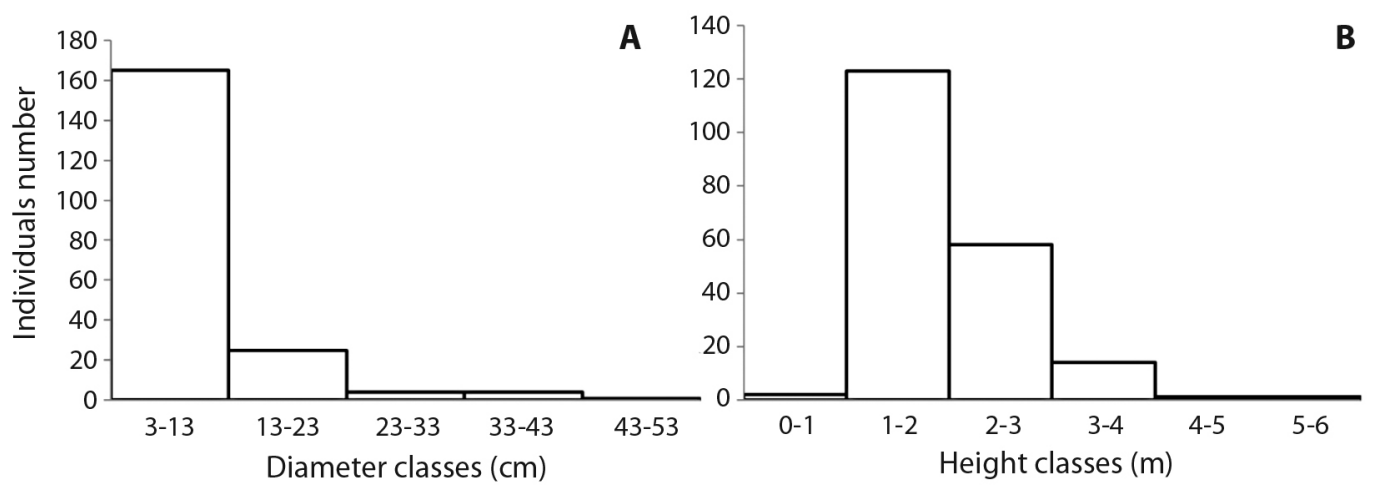

Fig. 3. A. Distribution of individuals by diameter classes (interval of $10 \mathrm{~cm}$ ), and $\mathbf{B}$. Distribution of the number of individuals by height class (interval of $1 \mathrm{~m}$ ) of the species of the restinga of Sitio Aguahy, São José de Ribamar, Maranhão state, Brazil.

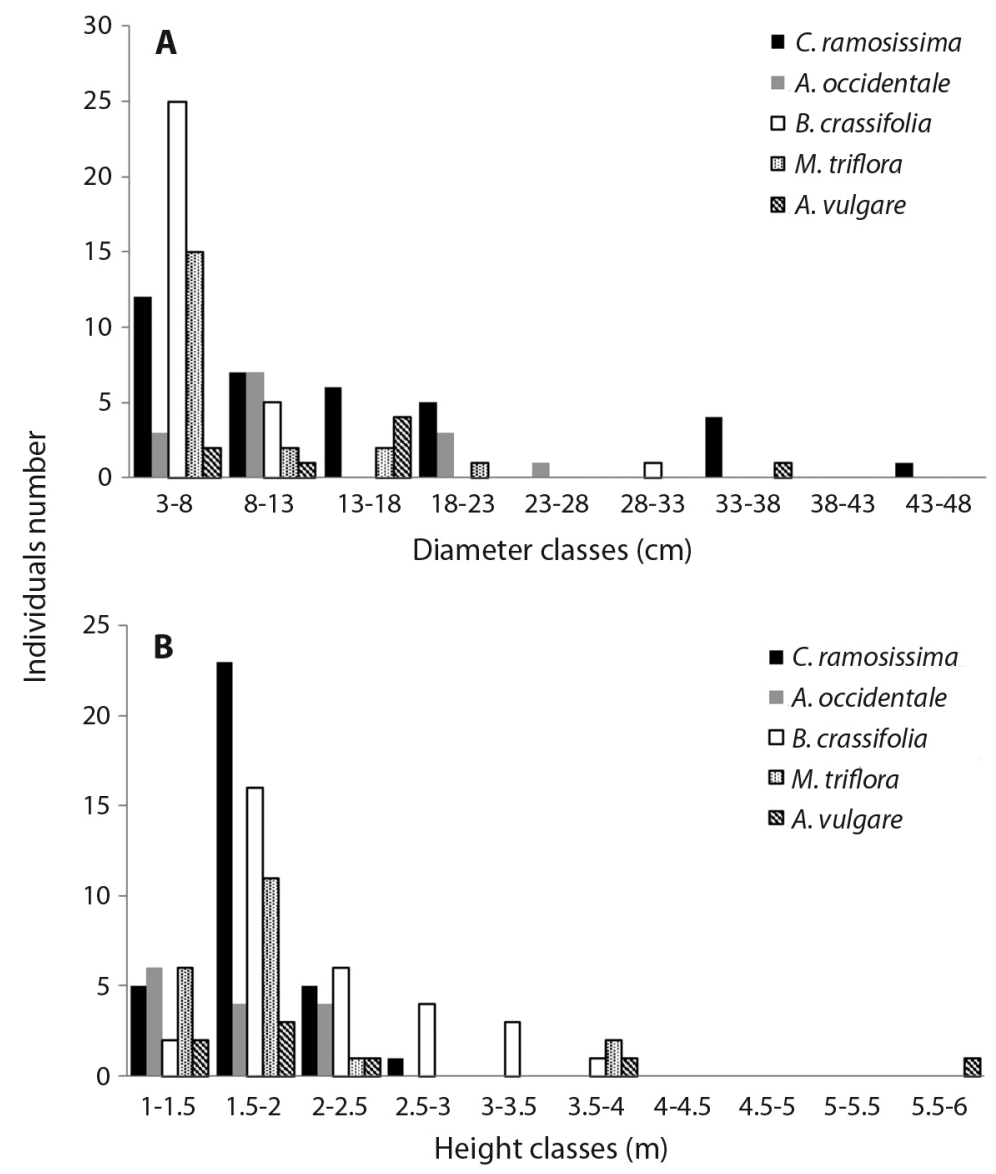

Fig. 4. A. Distribution of individuals by diameter classes (interval of $5 \mathrm{~cm}$ ); and B. Distribution of individuals by height class (interval of $50 \mathrm{~cm}$ ), for species of greater IV of the restinga of Sitio Aguahy, São José de Ribamar, Maranhão state, Brazil. 


\section{DISCUSSION}

The restinga in the present study showed values of diversity and equability (H' of 2.637 nat.ind ${ }^{-1}$ and $\mathrm{J}^{\prime}$ of 0.830 ) close to the values recorded in the restingas of the Northern coast, such as Ceará, Piauí, and Maranhão (Castro et al., 2012; Santos-Filho et al., 2013a; Machado \& Almeida Jr., 2019; Almeida Jr. et al., 2020). This fact may indicate that the species present more heterogeneous distribution due to the environmental peculiarities of each restinga, such as nutrient availability, acidity content, physical-chemical composition of the soil, and periodic flooding (Santos-Filho et al., 2013a).

Based on floristic data, Serra et al., (2016) highlighted the similarity between the restinga of the present study with the restingas of Pará, suggesting that Amazonian species contribute to the colonization of the Eastern coast of Maranhão, thus being able to direct new studies to expand knowledge on the areas of Amazonian vegetation in Maranhão.

The species found in the present study are widely distributed throughout the Brazilian territory, being found in different ecosystems, and not characterized as endemic to restinga areas (BFG, 2015). Despite this, restinga areas require attention due to their fragility faced with human actions, as deforestation and the consequent removal of superficial layers of soil interfere in the successional process of these areas, leading to possible losses in the diversity of species and ecological interactions. This demonstrates the need for conservation actions in the areas, since the restinga can serve as an ecological corridor for ecotonal areas (Castro et al., 2012; Serra et al., 2016).

The high number of individuals in the first diameter class together with the high density of species belonging to initial successional groups indicate that this area is in the process of regeneration, as had already been reported by Serra et al., (2016).

The horizontal distribution of study area had higher mean diameters in relation to other areas of restinga of the Northeast coast (Santos-Filho et al., 2013a; Machado \& Almeida
Jr., 2019; Almeida Jr. et al., 2020). This fact may be related to the significant number of branches, as observed in individuals of Anacardium occidentale, which naturally have many branches in restinga areas (Almeida Jr. Et al., 2011; Machado \& Almeida Jr., 2019; Almeida Jr., Correia, \& Santos-Filho, 2020). The branches of Coccoloba ramosissima may be associated with the regrowth ability and could be considered an important mechanism in the processes of recolonization in degraded areas. This may play an important role in forest restoration during the initial successional stages, since as climatic species are established, this process becomes rarer in the plant community (Mariano, Junior, Silva, \& Amorim, 2007; Chazdon, 2008).

The development of branches in species in restingas contributes positively to the establishment and growth of these plants (Sá, 2002). In this way, the diametric values, considering the sum of the branches, generate a large caliber, allowing these species to occupy more space, and so to compete and stand out in the woody stratum.

As for the size of the vegetation, it can be considered that in the restinga of the present study there was a greater predominance of shrubs and trees of low height, similar to the plants of restingas on the coast of the Piauí state (Santos-Filho et al., 2013a). The composition woody community from restinga of Curupu (Machado \& Almeida Jr., 2019) and from restinga of Alcântara (Almeida Jr. et al., 2020) in Maranhão state, and the restinga of Pecém, in Ceará state (Castro et al., 2012), it was taller, with a variation of 4 to $4.4 \mathrm{~m}$ in the average height of the individuals, in relation to the vegetation of the present study. This difference is probably due to the different physiognomies of restingas (Santos-Filho, Almeida Jr., Soares, \& Zickel, 2010) and by the diversity of species in each area. Furthermore, the area under study presents ecotonal vegetation, consisting mainly for species of the Amazonic biome and Cerrado biome (Serra et al., 2016; Machado \& Almeida Jr., 2019; Almeida Jr. et al., 2020), reinforcing the particularity regarding the structure 
of the woody vegetation of the restingas in Maranhão state.

Byrsonima crassifolia, registered along the restinga areas of the Northeast (Castro et al., 2012), is highlighted in the area by the expressive number of individuals. This species is important in the ecological relations of this restinga, such as for the pollination and construction of nests of pollinators (Mendes \& Rêgo, 2007).

Zickel et al. (2015) pointed out that Anacardium occidentale occurs in several restinga areas on the Northeast coast (Sacramento, Zickel, \& Almeida Jr., 2007; Cantarelli, Almeida Jr., Santos-Filho, \& Zickel, 2012b; Santos-Filho et al., 2013a), with the presence of branches being common. However, the predominance of this species in some restingas may be associated with the degree of degradation of the area or the economic interest, due to the commercial value of the fruits (the cashew) (Zickel et al., 2015).

With respect to the diametric and hypsometric distribution of Manilkara triflora, the presence of individuals that developed horizontally through branches, but did not grow vertically was noticed. This behavior can be explained by the characteristics of the soil, which can hinder the growth of the plant in stature (Passioura, 2002), or by the stressful conditions of the area, such as high soil salinity, in addition to the shallow soil, which tend to favor strategies such as growth and reproduction of the individual through branches (Sá, 2002; Fonseca, Ribeiro, \& Carvalho, 2013). This species, together with Manilkara bidentata, found in the study area, are Amazonian species and of economic interest. Although these species are not listed as endangered as a result of their wide distribution, they require attention due to the loss of habitat and exploitation for the use of wood in Maranhão, which could lead to a change in the conservation status of these species in a short time, which may compromise the community and structural arrangement of woody vegetation, especially in coastal areas which are the first to experience suppressed vegetation (Almeida Jr., Santos Filho, \& Zickel, 2012).
The gap observed in the height and diameter classes of Astrocaryum vulgare may suggest that a factor is hindering the establishment of adult individuals in the area or that a disturbance may have prevented the development of individuals. This species also stands out as it is an arborescent palm, capable of establishing quickly in disturbed environments with lots of light (Santos-Filho, Almeida Jr., \& Soares, 2013b). In addition to being important in the processes of regeneration and ecological succession, this species has the ability to recruit and rapidly modify the environment (SantosFilho et al., 2013b).

It is known that lists on floras and plant structures can be consulted to choose the species to be used in recovery actions (Ferreira et al., 2013). In habitats subjected to extreme environmental pressures, such as restinga areas, the most abundant species seem to provide adequate environmental conditions for the germination and growth of other species (Scarano, 2002).

The present study highlighted that regarding the succession level the vegetation presented characteristics of being in an initial stage, with respect to factors such as size and regrowth power. This could be important in regeneration processes, such as in recovery actions in other coastal areas or similar environmental conditions. The study also made it possible to highlight the use of species with the highest IV for maintenance and recovery in relation to species diversity and ecological interactions found in restingas. Finally, it is worth noting that "restinga" areas are among the most impacted ecosystems in Brazil, meaning studies on the conservation status of these environments are of great importance.

Declaración de ética: el autor declara que está de acuerdo con esta publicación; que no existe conflicto de interés de ningún tipo; y que ha cumplido con todos los requisitos y procedimientos éticos y legales pertinentes. Todas las fuentes de financiamiento se detallan plena y claramente en la sección de agradecimientos. 
El respectivo documento legal firmado se encuentra en los archivos de la revista.

\section{ACKNOWLEDGMENTS}

We thank Foundation for the Support of Research and Scientific and Technological Development of Maranhão (FAPEMA) for the financing of the project "Ilha do Maranhão: Estrutura, Diversidade e Distribuição da Vegetação de Restinga" (No 00663/14), and for the first author's scholarship. The Coordination for the Improvement of Higher Education Personnel - CAPES (finance code 001) by the granting the scholarship to the first author. The Pharmaceutical Company Quercegen Agronegocios I Ltda. for access to the area where the study was developed. David. B. Muniz for the elaboration of the map; to Kaue Dias, Gabriela Amorim, Aryana Vasquez, and Monielle Alencar for their immense and important support during the sampling of vegetation.

\section{RESUMEN}

\section{Fitosociología, nivel sucesional y conservación del componente leñoso de una "restinga" en isla Maranhão, Brasil}

Introducción: Las "restingas" pueden servir como corredor de especies en ambientes ecotonales debido a los aspectos de la composición de la flora. Los estudios a lo largo de la costa del estado de Maranhão son necesarios para comprender la diversidad y distribución de las especies de plantas presentes en las "restingas". Objetivo: El objetivo de este estudio fue caracterizar la estructura y conservación de la vegetación leñosa de una "restinga" en Maranhão. Métodos: Se realizó un muestreo fitosociológico de la vegetación leñosa utilizando cuadrantes, seguido de la clasificación de especies por grupo sucesional; además de analizar los datos diamétricos e hipsométricos de las poblaciones cuyas especies presentaron el de mayor valor importancia (VI). Resultados: En total, se identificaron 24 especies y 16 familias, $72 \%$ de los cuales fueron clasificados en las etapas iniciales de sucesión. Los valores de $\mathrm{H}^{\prime}$ y J' fueron 2.637 nat.ind $^{-1}$ y 0.830 , respectivamente. La altura y el diámetro medios fueron de 2.1 my 27.66 $\mathrm{cm}$, respectivamente. Las especies Coccoloba ramosissima Wedd., Byrsonima crassifolia (L.) Kunth, Anacardium occidentale L., Manilkara triflora (Allemão) Monach, y Astrocaryum vulgare Mart. presentaron los valores de mayor importancia (VI). Conclusiones: se observó que características como el tamaño, capacidad de rebrote y la facilidad de los procesos de regeneración podrían ser útiles para elegir las especies objetivo para las acciones de recuperación en las zonas costeras.

Palabras clave: fitosociología; estructura diamétrica; distribución vertical; estado de Maranhão; restauración ambiental.

\section{REFERENCES}

Alexandrino, V.H.D., Sousa, J.S., \& Bastos, M.N. (2011). Estudo taxonômico da família Malpighiaceae Juss. das restingas de Algodoal/Maiandeua, Maracanã, Pará, Brasil. Boletim Museu Paraense Emílio Goeldi Ciencias Naturais, 6(3), 335-347.

Almeida Jr., E.B., Santos-Filho, F.S., Araújo, E.L., \& Zickel, C.S. (2011). Structural characterization of the woody plants in restinga of Brazil. Journal of Ecology and the Natural Environment, 3(3), 95-103.

Almeida Jr., E.B., \& Zickel, C.S. (2012). Análise fitossociológica do estrato arbustivo-arbóreo de uma floresta de restinga no Rio Grande do Norte. Agrária, 7, 286-291.

Almeida Jr., E.B., Santos-Filho, F.S., \& Zickel, C.S. (2012). Conserving species of the Manilkara spp. threatened with extinction in vegetation fragments in ecotone zones. International Journal of Biodiversity and Conservation, 4(3), 113-117.

Almeida Jr., E.B., Correia, B.E.F., \& Santos-Filho, F.S. (2020). Diversidade e estrutura da comunidade lenhosa de uma restinga no litoral de Alcântara, Maranhão, Brasil. Acta Brasiliensis, 4(2), 85-90.

Amorim, G.S., Amorim, I.F.F., \& Almeida Jr., E.B. (2016a). Flora de uma área de dunas antropizadas na praia de Araçagi, Maranhão. Revista Biociências, 22(2), 18-29.

Amorim, I.F.F., Santos-Filho, F.S., \& Almeida Jr., E.B. (2016b). Fitossociologia do estrato herbáceo de uma área de dunas em Araçagi, Maranhão. In E.B. Almeida Jr., \& F.S. Santos-Filho (Eds.), Biodiversidade do Meio Norte do Brasil: conhecimentos ecológicos e aplicações (pp. 29-44). Curitiba, Brazil: Editora CRV.

APG IV. (2016). An update of the Angiosperm Phylogeny Group classification for the orders and families of flowering plants: APG IV. Botanical Journal of the Linnean Society, 181, 1-20.

Araujo, A.C.M., Silva, A.N.F., \& Almeida Jr., E.B. (2016). Caracterização estrutural e status de conservação do estrato herbáceo de dunas da Praia de São Marcos, Maranhão, Brasil. Acta Amazonica, 46(3), 247-258 
BFG The Brazil Flora Group. (2015). Growing knowledge: an overview of Seed Plant diversity in Brazil. Rodriguésia, 66, 1085-1113.

Cabral-Freire, M.C.C., \& Monteiro, R. (1993). Florística das praias da Ilha de São Luís, estado do Maranhão (Brasil): diversidade de espécies e suas ocorrências no litoral brasileiro. Acta Amazônica, 23(2-3), $125-140$

Cantarelli, J.R.R., Almeida Jr., E.B., Santos-Filho, F.S., \& Zickel, C.S. (2012a). Descrição da estrutura de uma vegetação de restinga da Área de Proteção Ambiental (APA) de Guadalupe, litoral sul de Pernambuco. In A.C.A. El-Deir, G.J.B. Moura, E.L. Araújo (Eds.), Ecologia e conservação de ecossistemas no Nordeste do Brasil (pp. 49-68). Recife, Brazil: NUPEEA.

Cantarelli, J.R.R., Almeida Jr., E.B., Santos-Filho, F.S., \& Zickel, C.S. (2012b). Tipos fitofisionômicos e florística da restinga da APA de Guadalupe, Pernambuco, Brasil. Insula, 41, 95-117.

Castro, A.S.F., Moro, M.F., \& Menezes, M.D. (2012). O complexo vegetacional da zona litorânea no Ceará: Pecém, São Gonçalo do Amarante. Acta Botanica Brasilica, 26, 108-124.

Chazdon, R.L. (2008). Chance and determinism in tropical forest sucession. In W.P. Carson, S.A. Schnitzer (Eds.), Tropical Forest Community Ecology (pp. 384408). Chichester, England: Blackwell Publishing Ltd.

Cottam, G., \& Curtis, J.T. (1956). The use of distance measures in phytosociological sampling. Ecology, $37(3), 451-460$.

Dias, H.M., \& Soares, M.L.G. (2008). As fitofisionomias das restingas do município de Caravelas (Bahia- Brasil) e os bens e serviços associados. Boletim TécnicoCientífico do CEPENE, 16(1), 59-74.

Durigan, G. (2003). Métodos para análise de vegetação arbórea. In L. Cullen Junior, R. Rudran, C. Valladares-Pádua (Eds.), Métodos de estudos em biologia da conservação e manejo da vida silvestre. Curitiba, Brazil: UFPR \& Fundação Boticário de Proteção à Natureza.

Ferreira, P.I., Gomes, J.P., Batista, F., Bernardi, A.P., Costa, N.D., Bortoluzzi, R.D., \& Mantovani, A. (2013). Espécies potenciais para recuperação de áreas de preservação permanente no Planalto Catarinense. Floresta e Ambiente, 20(2), 173-182.

Fonseca, S.N., Ribeiro, J.H.C., \& Carvalho, F.A. (2013). Estrutura e diversidade da regeneração arbórea em uma floresta secundária urbana (Juiz de Fora, MG, Brasil). Floresta e Ambiente, 20(3), 307-315.

Gandolfi, S., Leitão, H., \& Bezerra, C.L.F. (1995). Composição florística e estrutura fitossociológica do estrato arbóreo de mata mesófila semdecídua de encosta, no município de Guarulhos-SP. Revista Brasileira de Botânica, 55(4), 753-767.

INMET Instituto Nacional de Metereologia. (2016). BDMEP - Banco de Dados Meteorológicos para Ensino e Pesquisa. Retrieved from http://www.inmet. gov.br/portal/ index.php?r=bdmep/bdmep

Köppen, W. (1948). Climatologia: con un estudio de los climas de la terra. Ciudad de México, México: Fondo de Cultura Económica.

Lima, G.P., \& Almeida Jr., E.B. (2018). Diversidade e similaridade florística de uma restinga ecotonal no Maranhão, Nordeste do Brasil. Interciencia, 43(4), 275-282.

Lima, G.P., \& Almeida Jr., E.B. (2020). Synopsis of the tribe Cocoseae Mart. (Arecoideae, Arecaceae) in the state of Maranhão, Brazil. Biota Neotropica, 20(2), e20190922.

Machado, M.A., \& Almeida Jr., E.B. (2019). Spatial structure, diversity and edaphic factors of an area of Amazonian coast vegetation in Brazil. Journal of the Torrey Botanical Society, 146(1), 58-68.

Margalho, L.F., Rocha, A.E.S., \& Secco, R.S. (2009). Rubiaceae Juss. da restinga da APA de Algodoal/ Maiandeua, Maracanã, Pará, Brasil. Boletim Museu Paraense Emílio Goeldi Ciencias Naturais, 4(3), 303-339.

Mariano, K.R.S., Junior, C.A.S.M., Silva, K.K.A., \& Amorim, S.M.C. (2007). Decomposição e liberação de nutrientes da fração foliar de Coccoloba ramosissima Wedd. Revista Brasileira de Biociências, 5, 372.

Marinho, D., Muniz, D.B., \& Azevedo, G.G. (2018) Nesting biology of three Megachile (Hymenoptera: Megachilidae) species from Eastern Amazonia, Brazil. Revista Brasileira de Entomologia, 62, 97-106.

Medeiros, D.P.W., Santos-Filho, F.S., Almeida Jr., E.B., Pimentel, R.M.M., \& Zickel, C.S. (2010). Estrutura do componente lenhoso de uma restinga no litoral sul de Alagoas, Nordeste, Brasil. Revista Brasileira de Geografia Física, 3, 146-150.

Medeiros, D.P.W., Almeida Jr., E.B., Abreu, M.C., SantosFilho, F.S., \& Zickel, C.S. (2014). Riqueza e caracterização da estrutura lenhosa da vegetação de restinga de Baia Formosa, RN, Brasil. Pesquisas, Série Botânica, 65, 183-199.

Melo, E. (1996). Levantamento das espécies de Coccoloba (Polygonaceae) da restinga do estado da Bahia, Brasil. Sitientibus, 15, 49-59.

Mendes, F.N., \& Rêgo, M. (2007). Nidificação de Centris (Hemisiella) tarsata Smith (Hymenoptera, Apidae, Centridini) em ninhos-armadilha no Nordeste do Maranhão, Revista Brasileira de Entomologia, 51, 382-388. 
Menezes, C.M., Santana, F.D., Silva, V.S., Silva, V.I., \& Araújo, D.S. (2012). Florística e fitossociologia em um trecho de restinga no litoral norte do estado da Bahia. Biotemas, 25(1), 31-38.

Menezes, M.O.T., Taylor, N.P., Machado, M.C., Coelho, P.J.A., \& Correia, D. (2011). Diversity and distribution of Cactaceae in Ceará state, northeastern Brazil. Bradleya, 29, 13-42.

Nadkarni, N.M., Mcintosh, A.C.S., \& Cushing, J.B. (2008). A framework to categorize forest structure concepts. Forest Ecology and Management, 256(5), 872-882.

Passioura, J.B. (2002). Soil conditions and plant growth Plant, Cell \& Environment, 25(2), 311-318.

Peixoto, A.L., \& Maia, L.N. (2013). Manual de Procedimentos para herbários. Recife, Brazil: Universitária da UFPE.

Rosário, A.S., Secco, R.S., Amaral, D.D., Santos, J.U.M., \& Bastos, M.N.C. (2005) Flórula fanerogâmica das restingas do estado do Pará. Ilhas de Algodoal e Maiandeua - 2. Myrtaceae A. L. de Jussieu. Boletim Museu Paraense Emillio Goeldi Ciências Naturais, 1, 31-48.

Sá, C.F.C. (2002). Regeneração de um trecho de floresta de restinga na Reserva Ecológica Estadual de Jacarepiá, Saquarema, Estado do Rio de Janeiro: II-Estrato arbustivo. Rodriguésia, 53, 5-23.

Sacramento, A.C.S., Zickel, C.S., \& Almeida Jr., E.B. (2007). Aspectos florísticos da vegetação de restinga no litoral de Pernambuco. Revista Árvore, 31(6), 1121-1130.

Santana, J.P., Rocha, P.A., Oliveira, E.V.S., Prata, A.P.N., \& Ribeiro, A.S. (2020). Phytosociology of the shrubarboreal stratum of the Ibura National Forest, Northeastern Brazil: are 35 years sufficient to promote the regeneration of a forest fragment? Neotropical Biology and Conservation, 15(2), 89-106.

Santos, V.J., Zickel, C.S., \& Almeida Jr., E.B. (2015) Composição estrutural do estrato arbustivo-arbóreo de uma floresta de restinga no sul da Bahia, Brasil. Pesquisas, Botânica, 68, 257-269.

Santos-Filho, F.S., Almeida Jr., E.B., Soares, C.J.R.S., \& Zickel, C.S. (2010). Fisionomias das restingas do Delta do Parnaíba, Nordeste, Brasil. Revista Brasileira de Geografia Física, 3(3), 218-227.

Santos-Filho, F.S., Almeida Jr., E.B., \& Zickel, C.S. (2013a). Do edaphic aspects alter vegetation structures in the Brazilian restinga? Acta Botanica Brasilica, 27, 613-623.

Santos-Filho, F.S., Almeida Jr., E.B., \& Soares, C.J.R.S. (2013b.) Cocais: zona ecotonal natural ou artificial? Revista Equador, 2(1), 2-13.

Scarano, F.R. (2002). Structure, function and floristic relationships of plant communities in stressful habitats marginal to the Brazilian Atlantic rainforest. Annals of Botany, 90, 517-524.

Serra, F.C.V., Lima, P.B., \& Almeida Jr., E.B. (2016), Species richness in restinga vegetation on the Eastern Maranhão State, Northeastern Brazil. Acta Amazonica, 46(3), 271-280.

Shepherd, G.J. (2009). FITOPAC 2.1. Departamento de Biologia Vegetal, Universidade Estadual de Campinas. Retrieved from https://pedroeisenlohr.webnode. com.br/fitopac

Silva, A.N.F., Araujo, A.C.M., \& Almeida Jr., E.B. (2016a). Flora fanerogâmica das dunas da praia de São Marcos, São Luís, Maranhão. In E.B. Almeida Jr. \& F.S. Santos-Filho (Eds.), Biodiversidade do Meio Norte do Brasil: conhecimentos ecológicos e aplicações (pp. 11-28). Curitiba, Brazil: Editora CRV.

Silva, F.B., Santos, J.R.N., Feitosa, F.E.C.S., Silva, I.D.C., Araújo, M.L.S.D., Guterres, C.E., \& Neres, R.L. (2016b). Evidências de mudanças climáticas na região de transição Amazônia-Cerrado no Estado do Maranhão. Revista Brasileira de Meteorologia, 31(3), 330-336.

Siminski, A., Mantovani, M., dos Reis, M.S., \& Fantini, A.C. (2004). Sucessão florestal secundária no município de São Pedro de Alcântara, litoral de Santa Catarina: estrutura e diversidade. Ciência Florestal, 14, 21-33.

Souza, D.R., Souza, A.L., Gama, J.R.V., \& Leite, H.G. (2003). Emprego de análise multivariada para estratificação vertical de florestas Ineqüiâneas. Árvore, 27(1), 59-63.

Vicente, A., Almeida Jr., E.B., Santos-Filho, F.S., \& Zickel, C.S. (2014). Composição estrutural da vegetação lenhosa da restinga de Cabedelo, Paraíba. Revista de Geografia, 31(1), 183-196.

Zickel, C.S., Vicente, A., Silva, S.S.L., Santos-Filho, F.S., Soares, C.J.R.S., \& Almeida Jr., E.B. (2015). Vegetação lenhosa de uma restinga em Pernambuco: descrição estrutural e similaridade. Pesquisas, Série Botânica, 68, 271-285. 